\title{
Hazard Maps Help Save Lives and Property
}

Tational maps of earthquake
shaking hazards provide
information essential to creating
and updating the seismic design
provisions of building codes used
in the United States. Scientists
frequently revise these maps to
reflect new knowledge. Build-
ings, bridges, highways, and
utilities built to meet modern
seismic design provisions are
better able to withstand earth-
quakes, not only saving lives but
also enabling critical activities to
continue with less disruption.

America's first line of defense against earthquakes has historically been the construction of buildings that can withstand severe shaking. Cities and counties rely on the seismic design provisions in building codes to ensure that structures can resist earthquakes. The variations in the seismic threat across the country are depicted on special maps in building codes, called design maps, as zones or contours of different recommended levels of design for earthquake-resistant construction. These design maps are based on shaking-hazard maps prepared by U.S. Geological Survey (USGS) scientists and engineers as part of the National Earthquake Hazard Reduction Program (NEHRP).

National maps of the earthquake shaking hazard in the United States have been produced since 1948. Scientists revise these maps as new earthquake studies improve

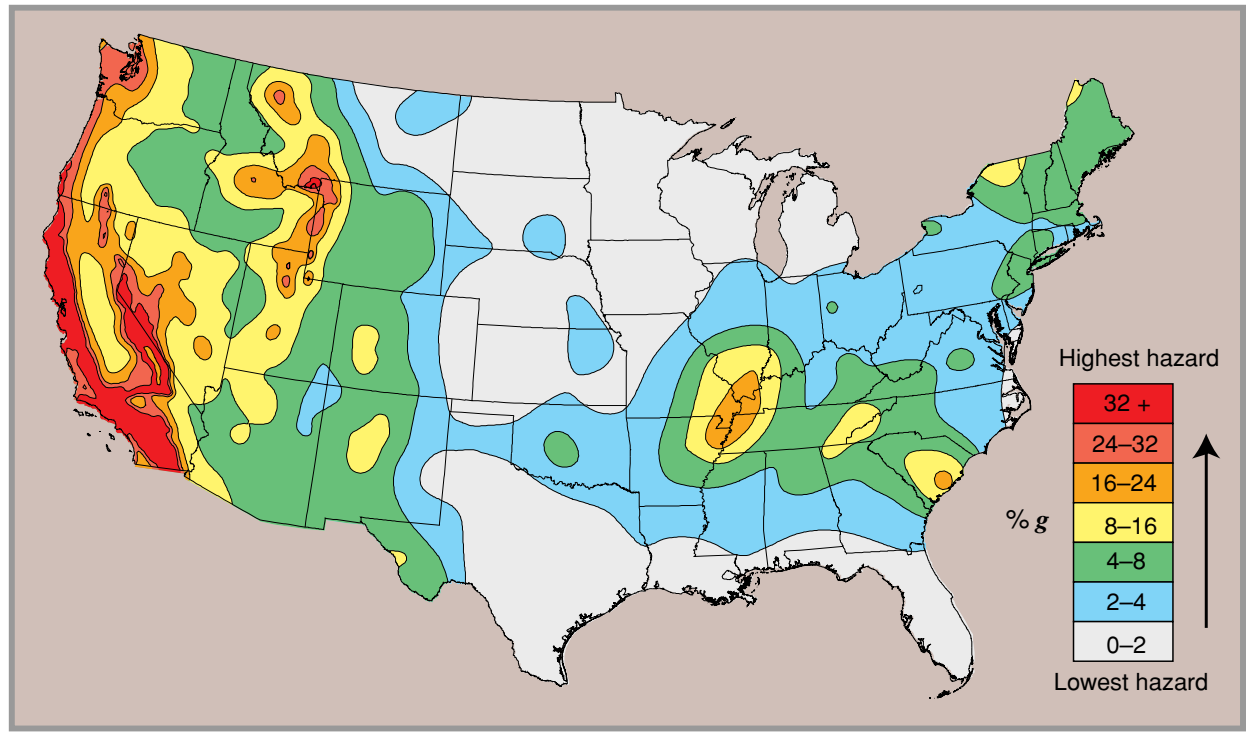

The 1996 U.S. Geological Survey shaking-hazard maps for the United States are based on current information about the rate at which earthquakes occur in different areas and on how far strong shaking extends from quake sources. Colors on this particular map show the levels of horizontal shaking that have a 1-in-10 chance of being exceeded in a 50-year period. Shaking is expressed as a percentage of $g(g$ is the acceleration of a falling object due to gravity).

their understanding of this hazard. After thorough review, professional organizations of engineers in turn update the seismic design maps and seismic design provisions contained in building codes. More than 20,000 cities, counties, and local government agencies use building codes, such as the Uniform Building Code, to help establish the construction requirements necessary to preserve public health and safety in earthquakes.

Shaking-hazard maps have many other applications. For example, the 1976 U.S. Geological Survey (USGS) shaking-hazard map for the United States was used for many years as the basis of design require-

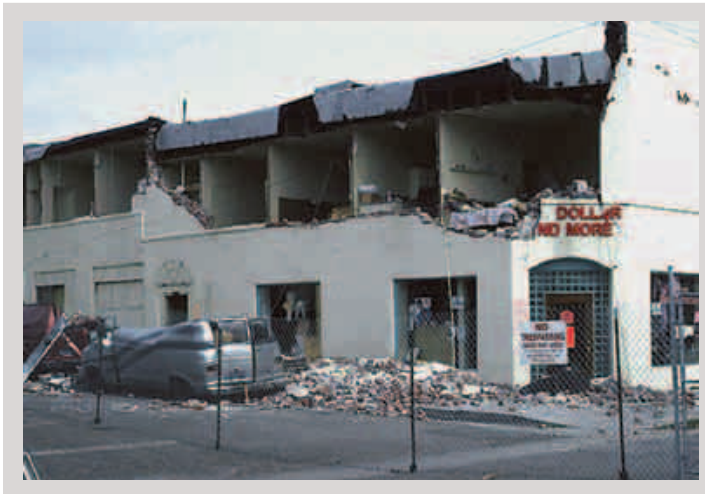

The upper wall of this unreinforced masonry building in Fillmore, California, collapsed and destroyed a parked vehicle during the 1994 Northridge earthquake. Unreinforced masonry buildings are especially susceptible to collapse or severe damage during strong earthquake shaking. Shaking-hazard maps can be used to determine if such buildings in a particular area need to be reinforced to make them safe in earthquakes. ments for highway bridges nationwide. Such maps are also used by:

- Insurance companies to set insurance rates for properties in various areas of the country,

- Civil engineers to estimate the stability and landslide potential of hillsides,

- The Environmental Protection Agency to set construction standards that help ensure the safety of waste-disposal facilities, and

- The Federal Emergency Management Agency (FEMA) to plan the allocation of assistance funds for earthquake education and preparedness.

A new series of national shaking-hazard maps was prepared by the USGS in 1996. Each of these maps shows the severity of expected earthquake shaking for a particular level of probability. For example, the map at the top of this page shows levels of earthquake shaking that have a 1-in-10 chance of being exceeded in a 50-year period. This new series of maps also depicts shaking using a number of different measures that engineers can readily apply to designing earthquake-resistant buildings of different heights. 


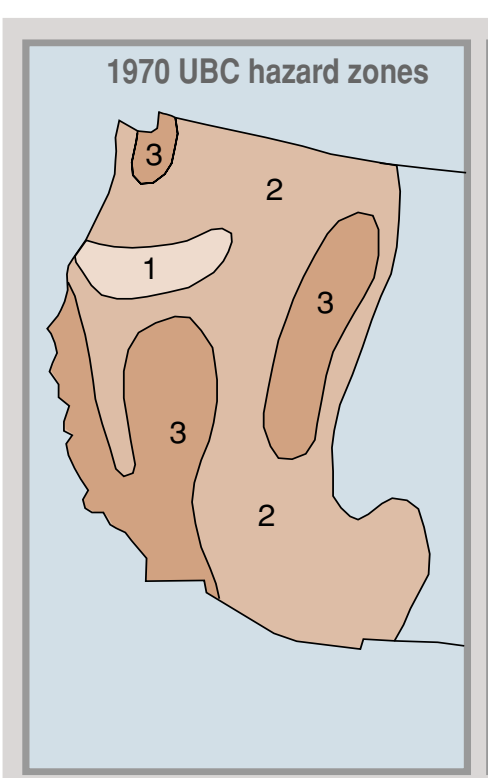

Shaking-hazard maps prepared by U.S. Geological Survey (USGS) scientists are used by professional organizations of engineers to improve the seismic-zone maps published in building codes, such as the Uniform Build-

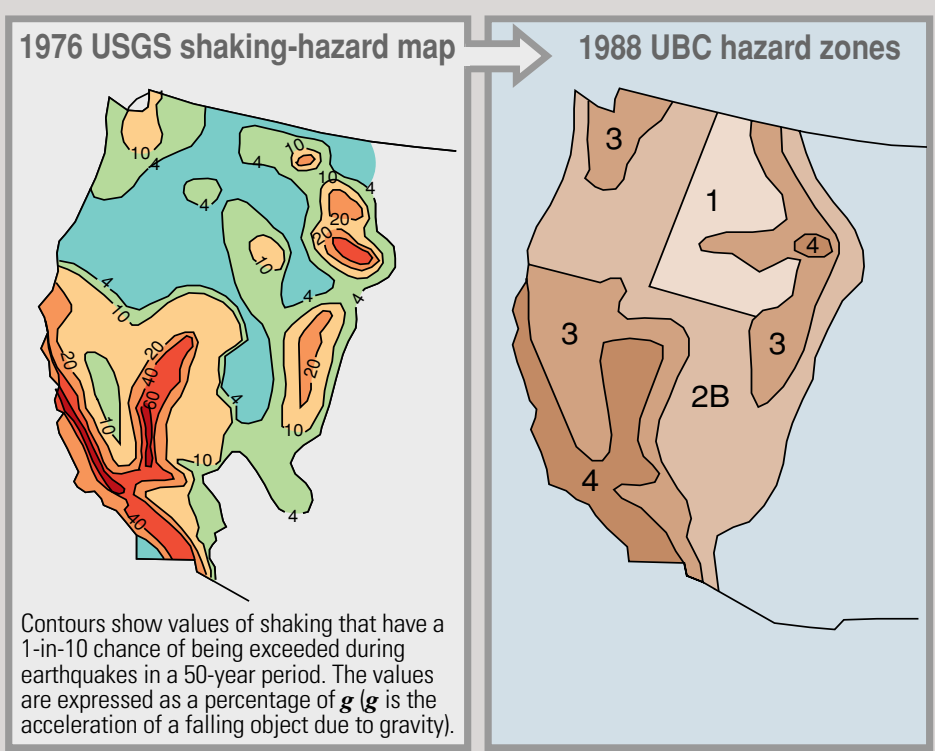

Design map from 1997 NEHRP Recommended Provisions

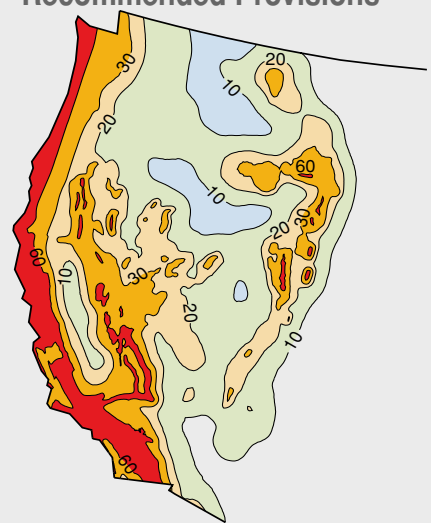

Contours show levels of horizontal response acceleration (as a percentage of $g$ ), for a building of 1-second natural period, that have a 1-in-50 chance of being exceeded during earthquakes in a 50 -year period. ing Code (UBC). The 1976 USGS shaking-hazard map represented a substantially improved understanding of the earthquake hazard nationwide and was used to produce the updated 1988 UBC seismic-zone map, which added zone 4 to represent a newly recognized higher level of haz ard. Contours from 1996 USGS hazard maps are used in the 1997 map from the "NEHRPRecommended Provisions" published by the Building Seismic Safety Council (BSSC).
Shaking-hazard maps can be combined with data about the strength of existing buildings to estimate expected earthquake damage in an area over a given period of time. Although strong earthquakes are less frequent in the Central and Eastern United States than in California, damage in those regions could be catastrophic in a powerful

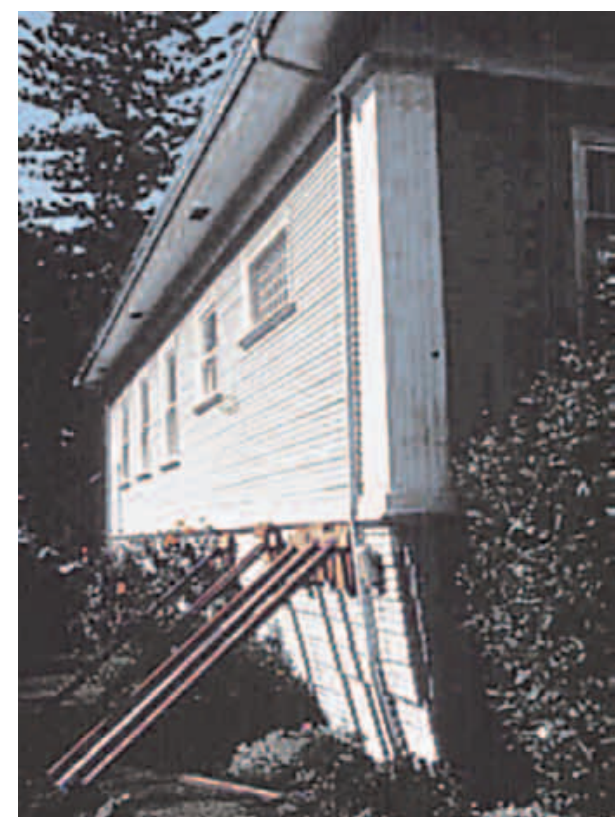

This home in Santa Cruz, California, damaged in the 1989 Loma Prieta earthquake, shows the effects of a weak "cripple-wall" connection between the upper part of the house and its foundation. Houses without adequate connections to foundations can easily shift during even moderate earthquake shaking, causing extensive damage. For example, pipes and wires may be broken by a slight cripple-wall shift, resulting in fires, water damage, or other problems. Much damage of this type can be avoided by using inexpensive bracing techniques, such as those recommended in the seismic design provisions of building codes. temblor. This is because most buildings and other structures there have not been constructed to withstand severe earthquake shaking. For example, the shaking hazard in Boston is far lower than that in Los Angeles, but a strong earthquake striking the Boston area today could produce much greater damage to structures than one striking Los Angeles. A single earthquake in the Central or Eastern United States could cause as many casualties and as much damage as several earthquakes of similar magnitude in California.

To familiarize design engineers, local public officials, emergency-services personnel, and other users with shaking-hazard maps and earthquake risk issues, the USGS conducts workshops throughout the country. These seminars have, for example, been held in New York, Memphis, Salt Lake City, San Francisco, and Seattle, and will continue in these and other places in the future. As new maps are prepared, the latest shaking-hazard maps will also be available for examination and comment on the Internet at http://geohazards.cr.usgs.gov/eq/index.html.

Recently, the USGS worked with the FEMA-funded Building Seismic Safety Council (BSSC) to produce new seismic design maps for the United States, based on the 1996 USGS shaking-hazard maps. The new design maps were published by the BSSC in its 1997 and 2000 "NEHRP Recommended Provisions for Seismic Regulations for New Buildings and Other Structures." These maps have been included in the seismic provisions of U.S. model building codes, such as the new "International Building Code," and in national standards such as "Minimum Design Loads for Buildings and Other Structures," prepared by the American Society of Structural Engineers.

Through the continuing process of refining estimates of the earthquake-shaking hazard across the Nation and observing successes and failures in building design, scientists and engineers are laying the groundwork for future urban environments that will be safer in earthquakes. By improving the resistance of homes, office buildings, hospitals, highways, dams, and utilities to earthquake shaking, scientists and engineers also help to ensure that communities are able to recover rapidly following a major temblor.

William M. Brown III, David M. Perkins, Edgar V. Leyendecker, Arthur D. Frankel, James W. Hendley II, and Peter H. Stauffer

\section{Graphic design by}

Sara Boore and Susan Mayfield

COOPERATING AGENCIES

American Assoc. of State Hwy. Transportation Officials American National Standards Institute American Society of Civil Engineers Applied Technology Council

Building Officials and Code Administrators International Building Seismic Safety Council

California Division of Mines and Geology

Environmental Protection Agency

Federal Emergency Management Agency International Conference of Building Officials

National Center for Earthquake Engineering Research National Oceanic and Atmospheric Administration

Southern Building Code Congress

Southern California Earthquake Center

Structural Engineers Association of California

For more information contact:

Earthquake Information Hotline (650) 329-4085

U.S. Geological Survey, Mail Stop 977

345 Middlefield Road, Menlo Park, CA 94025 http://quake.wr.usgs.gov 